\title{
Polychlorinated Biphenyls and Biotransformation Enzymes in Three Species of Sea Turtles from the Baja California Peninsula of Mexico
}

\author{
K. L. Richardson · M. Lopez Castro • \\ S. C. Gardner · D. Schlenk
}

Received: 26 March 2009/ Accepted: 29 June 2009/Published online: 22 July 2009

(c) The Author(s) 2009. This article is published with open access at Springerlink.com

\begin{abstract}
Concentrations of polychlorinated biphenyls (PCBs) as well as the expression patterns of cytochrome P450 (CYP) enzymes and glutathione- $S$-transferase (GST) activities were measured in livers of loggerhead (Caretta caretta), green (Chelonia mydas), and olive ridley (Lepidocheyls olivacea) sea turtles from the Baja California peninsula of Mexico. The mean concentrations of total PCBs were $18.1,10.5$, and $15.2 \mathrm{ng} / \mathrm{g}$ wet weight (ww) respectively for the three species and PCB 153 was the dominant congener in all samples. Total PCB concentrations were dominated by penta- and hexa-chlorinated biphenyls. The mean estimated TEQs were 42.8, 22.9, and $10.4 \mathrm{pg} / \mathrm{g}$ (ww) for loggerhead, green, and olive ridley, respectively, and more than $70 \%$ was accounted for by non-ortho PCBs. Western blots revealed the presence of hepatic microsomal proteins that cross-reacted with antiCYP2K1 and anti-CYP3A27 antibodies but not with antiCYP1A antibody. There were no significant differences in GST activities between species. Grouping congeners based on structure-activity relationships for CYP isoenzymes suggested limited activity of CYP1A contribution to PCB biotransformation in sea turtles. These results suggest potential accumulation of PCBs that are CYP1A substrates and provide evidence for biotransformation capacity, which differs from known animal models, highlighting the
\end{abstract}

K. L. Richardson · D. Schlenk $(\bowtie)$

Department of Environmental Sciences, University of California, Riverside, Riverside, CA 92521, USA

e-mail: daniel.schlenk@ucr.edu

M. Lopez Castro · S. C. Gardner

Centro de Investigaciones Biologicas del Noroeste,

S.C., Mar Bermejo \#195, Col. Playa Palo de Santa Rita,

AP 128, CP 23090 La Paz, BCS, Mexico need for further studies in reptiles, particularly those threatened with extinction.

The coast of the Baja California (BC) peninsula of Mexico serves as a critical feeding and developmental area for sea turtles (Clifton et al. 1982). Five of the world's seven extant sea turtles species can be found along BC: leatherback (Dermochelys coriacea), hawksbill (Eretmochelys imbricata), olive ridley (Lepidochelys olivacea), green (Chelonia mydas), and loggerhead (Caretta caretta). All of the world's seven species of sea turtles are globally considered critically endangered, endangered, or vulnerable (IUCN 2008), and throughout their life span, sea turtles face many hazards from human activity, including pollution and pathogenic infections (Mast et al. 2005). Organochlorine compounds, such as polychlorinated biphenyls (PCBs), have ecotoxicological significance as environmental contaminants because of their persistent nature, accumulation, and biomagnification through the food web (James 2001). Yet, compared to other taxa such as fish or mammals, relatively few studies have focused on levels of environmental contaminants such as PCBs in sea turtles worldwide (Corsolini et al. 2000; Keller et al. 2004b, c; Lake et al. 1994; McKenzie et al. 1999; Miao et al. 2001; Rybitski et al. 1995; Storelli et al. 2007; Storelli and Marcotrigiano 2000) and only one other study has been conducted in the BC region (Gardner et al. 2003). No data exist on threshold levels for toxicity of these compounds in sea turtles or reptiles. With life-history traits optimized for reproductive success throughout their long life span, turtle populations might be particularly susceptible to the accumulation of persistent environmental contaminants (Rowe 2008). 
Within the food chain, PCBs are subject to biotransformation by xenobiotic metabolizing enzymes to different degrees. This highly conserved transformation process generally occurs in the liver and/or intestines of vertebrates. Initial metabolism reactions typically involve the introduction of a functional group such as oxygenation by the cytochrome P450 (CYP) mono-oxygenases, typically resulting in an increase in hydrophilicity. The CYP enzyme system is critical to the metabolism of both exogenous and endogenous chemicals, with CYP families 1, 2, and 3 considered the most important for xenobiotic metabolism in vertebrates. Additional transformation reactions include conjugation of the xenobiotic with various polar endogenous moieties, such as glutathione (GSH) by glutathione- $S$ transferases (GST). Conjugation results in a large increase in hydrophilicity of the metabolite, thereby aiding its elimination. Exposure to coplanar or dioxinlike PCBs enhance CYP1 family expression and exposure to globular or nonplanar PCBs has been shown to increase expression of CYP2 and CYP3 families particularly in mammals (Safe 1994). In addition to modifying expression, PCBs are substrates for CYP1A or CYP2B subfamilies in mammals based on the position of vicinal protons within the congener (Boon et al. 1989; McFarland and Clarke 1989; Parke 1985). Xenobiotic accumulation can be alleviated by enhanced biotransformation, which can occur by exposure to enzyme-inducing agents. PCBs provide a unique situation in which specific enzyme substrates might also induce the same enzyme and potentially their own biotransformation.

Polychlorinated biphenyl congeners can be separated into four metabolic groups based on structure-activity relationships described by Kannan et al. (1995). Group 1, considered nonmetabolizable, consists of congeners that lack meta-para ( $m-p)$ and ortho-meta $(o-m)$ vicinal protons. Group 2, metabolized by CYP2B in mammals, consists of congeners that have only $m-p$ vicinal protons. Group 3, metabolized by CYP1A in mammals, consists of congeners that have only $o-m$ vicinal protons. Group 4, considered readily metabolizable as both of the above enzyme families can oxidize these congeners, consists of congeners that have both $m-p$ and $o-m$ vicinal protons. Through the comparison of congener profiles with expression patterns of biotransformation enzymes, a better understanding of PCB metabolism and accumulation can be attained.

The present study measured the concentrations of PCBs in the livers of three species of sea turtles-loggerhead, green, and olive ridley-from the Baja California peninsula of Mexico and evaluated species-specific variation in PCB accumulation. Congeners that bind the aryl hydrocarbon receptor (AhR) were grouped into toxic equivalency units (Van den Berg et al. 1998). Finally, profiles of CYP isoform and GST activities were compared to PCB congeners to explore biotransformation and accumulation differences among the three species of sea turtles.

\section{Materials and Methods}

Chemicals

Optima-grade acetone and hexane, as well as ACS plusgrade sulfuric acid were purchased from Fisher Scientific (Pittsburgh, PA, USA). The PCB standards were purchased from AccuStandard Inc. (New Haven, CT, USA). GSH and 1-chloro-2,4-dinitrobenzene (CDNB) were purchased from Sigma Chemical (St. Louis, MO, USA). Various buffers, salts, and cofactors were purchased from Fisher Scientific or Sigma Chemical.

\section{Sample Collection}

Between 2001 and 2003, samples of liver tissue were collected from stranded wild-born loggerhead, green, and olive ridley turtles from the waters surrounding the Mexican states of BC and Baja California Sur (see Fig. 1). Tissue samples were obtained as a result of natural mortality, incidental fisheries, or unknown causes of death and were only collected from animals for which time of death could be approximated within $24 \mathrm{~h}$. Turtles were necropsied and a sample of liver tissue was placed in aluminum foil and stored on ice for transport and then stored at $-80^{\circ} \mathrm{C}$ until analysis. Table 1 provides specific features of the sampled individuals.

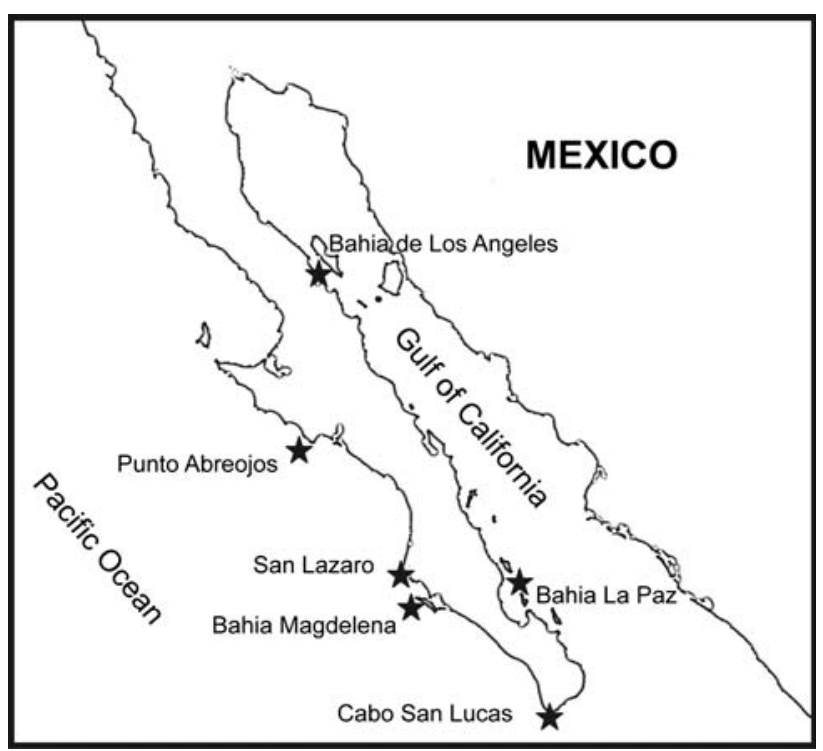

Fig. 1 A map of the Baja California peninsula. Stars indicate sampling locations 
Table 1 Dietary preferences of adult sea turtles and information on individual specimens used in this study

Source: Richardson et al. (2009)

\begin{tabular}{|c|c|c|c|c|c|}
\hline \multirow[t]{2}{*}{ Species } & \multirow{2}{*}{$\begin{array}{l}\text { Common } \\
\text { name }\end{array}$} & \multirow{2}{*}{$\begin{array}{l}\text { Preferred } \\
\text { food }\end{array}$} & \multicolumn{3}{|c|}{ Specimen information } \\
\hline & & & ID & $\begin{array}{l}\text { Carapace } \\
\text { length }(\mathrm{cm})\end{array}$ & Sex \\
\hline \multirow[t]{4}{*}{ Chelonia mydas } & \multirow[t]{4}{*}{ Green } & \multirow[t]{4}{*}{ Sea grass, algae } & CM-1 & 52.5 & Female \\
\hline & & & CM-2 & 58.5 & Unknown \\
\hline & & & $\mathrm{CM}-3$ & 50 & Unknown \\
\hline & & & $\mathrm{CM}-4$ & 55 & Male \\
\hline \multirow[t]{4}{*}{ Caretta caretta } & \multirow[t]{4}{*}{ Loggerhead } & \multirow[t]{4}{*}{ Benthic invertebrates } & $\mathrm{CC}-1$ & 55 & Male \\
\hline & & & $\mathrm{CC}-2$ & 66.5 & Unknown \\
\hline & & & $\mathrm{CC}-3$ & 62 & Female \\
\hline & & & $\mathrm{CC}-4$ & 57 & Unknown \\
\hline \multirow[t]{4}{*}{ Lepidochelys olivacea } & \multirow[t]{4}{*}{ Olive ridley } & \multirow[t]{4}{*}{ Fish, salps } & LO-1 & 61 & Unknown \\
\hline & & & LO-2 & 57 & Unknown \\
\hline & & & LO-3 & 61.5 & Unknown \\
\hline & & & $\mathrm{LO}-4$ & 53 & Unknown \\
\hline
\end{tabular}

Chemical Analysis

Approximately $3 \mathrm{~g}$ of liver tissue from four loggerhead, three green, and four olive ridley turtles was spiked with PCB 65 surrogate standard prior to homogenization with anhydrous sodium sulfate, followed by extraction with hexane using an ultrasonic disruptor (550 Sonic Dismembrator; Fisher Scientific) according to EPA method 3550B as described elsewhere (Sapozhnikova et al. 2004). The extract was evaporated to $2 \mathrm{~mL}$ and $250 \mu \mathrm{L}$ were removed for gravimetric lipid determination. The remaining extract was treated by vigorous vortexing with $2 \mathrm{~mL}$ of hexanecleaned concentrated sulfuric acid. The acid layer was then back-extracted two times with hexane and the hexane fractions were combined and evaporated to $0.25 \mathrm{~mL}$ for gas chromatograph-electron capture detector (GC-ECD) analysis.

Sample extracts were amended with the internal standard PCB 30 prior to analysis using a Hewlett Packard HP6890 gas chromatograph equipped with a ${ }^{63} \mathrm{Ni}$ electron capture detector (Wilmington, DE, USA) with hydrogen and nitrogen used as carrier and make-up gases, respectively. The column, a $60-\mathrm{m} \times 0.25$-mm-inner diameter DB-5MS fused silica (J\&W; Agilent Technologies, Santa Clara, CA, USA), was programmed from 50 to $200^{\circ} \mathrm{C}$ at $30^{\circ} \mathrm{C} / \mathrm{min}$, held at this temperature for $1 \mathrm{~min}$, raised to $220^{\circ} \mathrm{C}$ at $3^{\circ} \mathrm{C} / \mathrm{min}$, held at this temperature for $1 \mathrm{~min}$, raised to $255^{\circ} \mathrm{C}$ at $1.5^{\circ} \mathrm{C} / \mathrm{min}$, and then raised to $290^{\circ} \mathrm{C}$ at $2^{\circ} \mathrm{C} / \mathrm{min}$ and held at this temperature for $5 \mathrm{~min}$. The chemical identity was verified using a $60-\mathrm{m} \times 0.25-\mathrm{mm}$ inner diameter DB-35 fused-silica column (J\&W) programmed from 50 to $190^{\circ} \mathrm{C}$ at $1.5^{\circ} \mathrm{C} / \mathrm{min}$ and then raised to $320^{\circ} \mathrm{C}$ at $3.5^{\circ} \mathrm{C} / \mathrm{min}$. The inlet and detector temperatures were 250 and $310^{\circ} \mathrm{C}$, respectively.
Quantification of individual PCB congeners (IUPAC PCB $8,18,28,44,52,66,77,81,101,105,114,118,123,126,128$, $138,153,156,157,167,169,170,180,187,189,195,206$, and 209) was performed using the relative response factors generated from the calibration curve of standards (Mullin et al. 1984). The total PCB (tPCB) concentration in samples was defined as the sum of these congeners.

Analytical performance was monitored using blanks, spiked samples, and surrogate recovery in all samples. PCB recoveries ranged from $70 \%$ to $95 \%$ and from $71 \%$ to $103 \%$ for spiked samples and surrogates, respectively. The method detection limit ranged from 0.02 to $0.25 \mathrm{ng} / \mathrm{g}$.

Polychlorinated biphenyl congeners are present in the environment as mixtures, but the concentration of each congener in various compartments is controlled by physiochemical as well as biological processes. PCB 153, which is ubiquitous in the environment, lacks vicinal protons and, therefore, is generally considered recalcitrant to biotransformation (Safe 1984). In order to examine the metabolic influence on PCB profiles, metabolic ratios for each congener were calculated as molar PCB X/PCB 153 (Kannan et al. 1995).

\section{Toxic Equivalency Calculations}

2,3,7,8-Tetrechlorodibenxo- $p$-dioxin (TCDD) equivalents (TEQs) were estimated for non-ortho and mono-ortho dioxinlike PCBs using bird toxic equivalency factors (TEFs) reported in 1998 by the World Health Organization (Van den Berg et al. 1998). Because TEFs have not been established for reptiles (but are available for mammals, fish, and birds), bird TEFs were selected because of the three taxa; birds are most similar to reptiles. 


\section{Isolation of Subcellular Fractions}

Liver tissue (1-2 g/sample) from each sea turtle sample, as well as liver from laboratory-reared rainbow trout $(\mathrm{On}$ corhynchus mykiss) for use as controls, was homogenized at $4^{\circ} \mathrm{C}$ in buffer $(1: 4 \mathrm{w} / \mathrm{v})$ containing $0.1 \mathrm{M}$ Tris $-\mathrm{HCl}$, $0.15 \mathrm{M} \mathrm{KCl}, 1 \mathrm{mM}$ EDTA, and $0.1 \mathrm{mM}$ phenylmethanesulfonylfluoride (PMSF), pH 7.4, with a Wheaton tissue grinder with a Teflon pestle (Wheaton Scientific Products, Millville, NJ, USA). The subcellular fractions were isolated by sequential centrifugation at $20,000 \mathrm{~g}$ for $30 \mathrm{~min}$ and then at $100,000 \mathrm{~g}$ for $90 \mathrm{~min}$, both performed at $4^{\circ} \mathrm{C}$ to prevent protein degradation. After the final spin, the supernatant (cytosolic fraction) was aliquoted to clean tubes, and the pellet (microsomal fraction) was resuspended in buffer containing $0.1 \mathrm{M}$ potassium phosphate buffer, $\mathrm{pH} 7.4$, with $20 \%$ glycerol and aliquoted. All subcellular fractions were then stored at $-80^{\circ} \mathrm{C}$ until analysis. Protein concentrations of the fractions were determined using the microassay Bradford method (Brogdon and Dickinson 1983), stained with Coomassie Plus and bovine serum albumin as a standard (both Pierce Biotechnology Inc, Rockford, IL, USA).

\section{Anti-CYP Western Blotting}

Due to limited biomass, profiles of CYP isoforms in sea turtles were evaluated by Western blotting using CYP antiserum raised against fish CYP isoforms because antibodies for sea turtle CYP isoforms are not available. Microsomal proteins (50 $\mu \mathrm{g}$ per lane), along with molecular-weight markers (SeeBlue Plus2; Invitrogen, Carlsbad, CA, USA) were resolved using polyacrylamide gels [sodium dodecyl (SDS)-PAGE, 10\% gradient]. Four loggerhead, six green, and six olive ridley samples were used for these analyses. Rainbow trout microsomes from animals pretreated with $\beta$-naphthoflavone $(25 \mathrm{mg} / \mathrm{kg}$ twice over 4 days) were used as positive controls and were run on each gel for densitometry normalization. Resolved proteins were transferred to $0.45-\mu \mathrm{m}$ nitrocellulose membranes using semidry transfer. Membranes were blocked with 5\% nonfat milk in Tris-buffered saline (TBS; $20 \mathrm{mM}$ Tris, $150 \mathrm{mM} \mathrm{NaCl}, \mathrm{pH}$ 7.5) for at least $30 \mathrm{~min}$. Primary antibodies consisted of mouse anti-fish monoclonal CYP1A (Biosense, Bergen, Norway) and rabbit anti-rainbow trout polyclonal CYP2K1 and CYP3A27 antibodies (provided by Dr. D. R. Buhler, Oregon State University). Goat anti-mouse (CYP1A) and anti-rabbit (CYP2K1, CYP3A27) IgG alkaline phosphatase was used as the secondary antibody (BioRad, Hercules, CA, USA). Bands were visualized using a commercial alkaline phosphatase substrate conjugation kit (Bio-Rad). Blots were scanned using a Biorad GelDoc. After measuring the density of each band with Quantity One software (Bio-Rad), bands were normalized to the rainbow trout control run on each gel and express as relative optical density.

\section{GST Activities}

Cytosolic GST activities toward 1-chloro-2,4-dinitrobenzene (CDNB) were determined spectrophotometrically using the assays of Habig and Jakoby (1981). Four loggerhead, four green, and four olive ridley samples were used for these analyses. Catalytic activity assays were conducted at $25^{\circ} \mathrm{C}$, at $\mathrm{pH} 7.2$, and were corrected for nonenzymatic activity. CDNB was dissolved in ethanol and prepared so that the final concentration of ethanol was less than $0.01 \%$ in the reaction. The reaction mixture $(1 \mathrm{~mL}$ final volume) contained $30 \mu \mathrm{g}$ of cytosolic protein, along with $1 \mathrm{mM}$ CDNB, $1 \mathrm{mM}$ GSH, and assay buffer $[0.1 \mathrm{M}$ phosphate ( $\mathrm{pH}$ 7.2)]. The reaction was started, after a 7-min preincubation of GSH and protein in buffer, by adding $\mathrm{CDNB}$, and the linear portion of change of absorbance was monitored over time. The duration and optimization of conditions was determined in previous studies (Richardson et al. 2009).

\section{Statistical Procedures}

Statistical analyses [analysis of variance (ANOVA) and linear regression] were carried out using Minitab ${ }^{\circledR}$ for Windows software (Minitab Inc., State College, PA, USA) and Prism 5 for Windows software (Graphpad Software Inc., La Jolla, CA, USA). PCB concentrations on a wetweight basis were analyzed. For individual PCB congeners below detection limits, a random number between the detection limit and one-half of the detection limit was used for statistical analysis.

The GST activities were analyzed once corrected for nonenzymatic activity. For regression analysis, only data points for which both end points were available were included and outliers were removed when appropriate. If an overall significance was detected by ANOVA, Tukey's tests were performed in order to determine differences among species or groups. Results are presented as means \pm standard deviation. A $p$-value of less than 0.05 was considered significant.

\section{Results}

\section{PCB Concentrations}

Polychlorinated biphenyl concentrations and lipid content for loggerhead, green, and olive ridley turtles are given in Table 2 and the pattern of PCB congeners in all three 


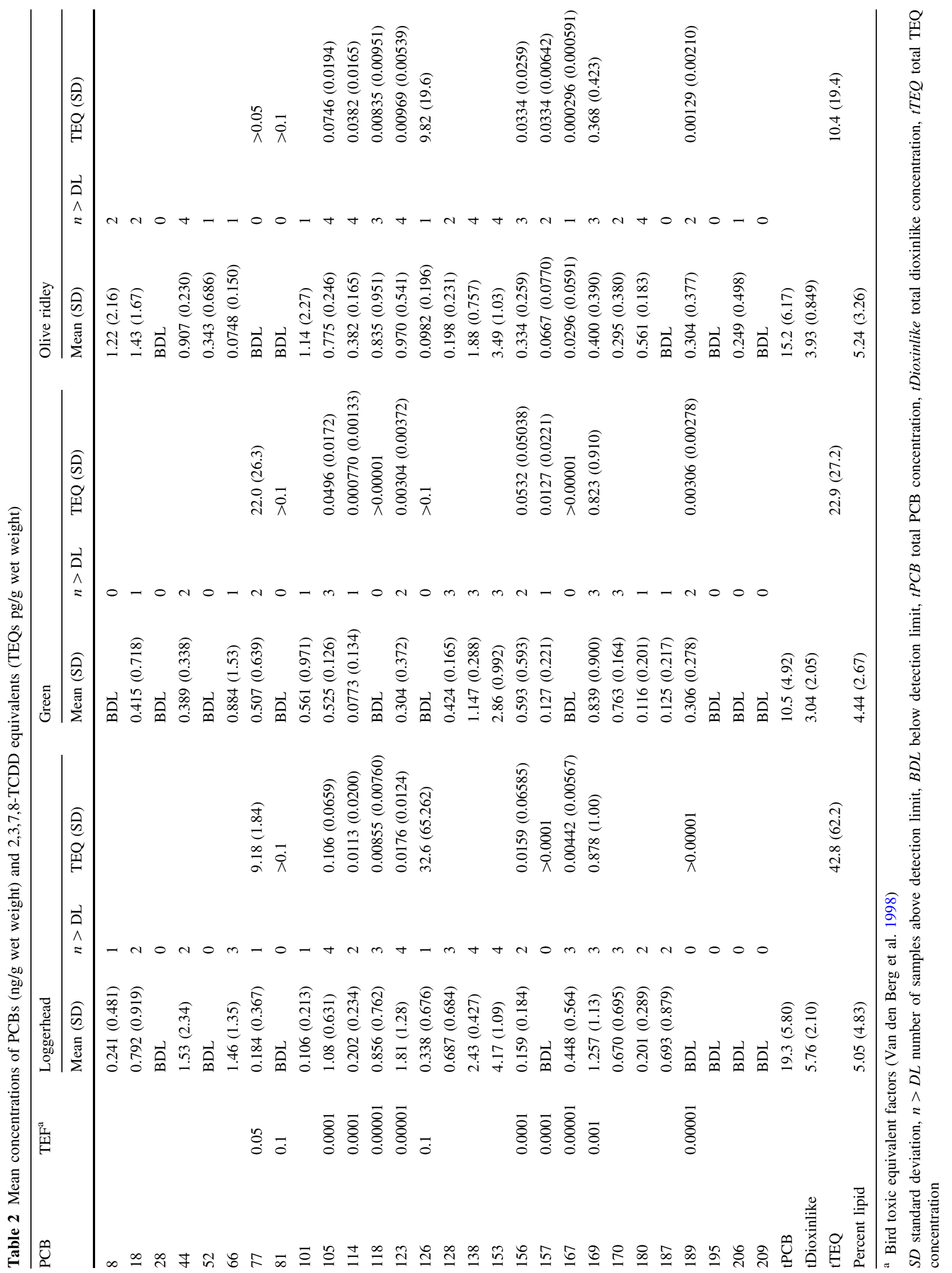


species are given in Fig. 2. Lipid content varied among individual samples $(0.787-10.7 \%)$ but did not significantly differ across species $(p=0.96)$. Furthermore, regression analysis showed no relationship between lipid content and tPCB wet-weight concentrations (data not shown). Thus, wet-weight concentrations were used for further analysis.

In each sample, the number of congeners detected ranged from 7 to 17. Several PCB congeners $(28,81,195$, and 209) were not detected in any sample and were removed from further analysis. Three congeners that were detected in all samples-105, 138, and 153-constituted 33-62\% of the tPCB concentration in each sample, with 153 as the most abundant congener (Table 2). The tPCB concentration was determined as the sum of the concentrations of each congener detected in any particular sample. Total PCB concentrations ranged considerably, from $5.23 \mathrm{ng} / \mathrm{g}$ in one green turtle to $24.9 \mathrm{ng} / \mathrm{g}$ in one loggerhead turtle. Mean tPCB concentrations were 18.1, 10.5, and 15.2 for loggerhead, green, and olive ridley turtles, respectively. However, no significant differences were found in the tPCB concentrations among species $(p=0.451)$. In the green turtles, a negative trend was found between carapace length $(\mathrm{CL})$ and $\mathrm{PCB}$ concentration $\left(r^{2}=0.99, p=0.06\right)$, yet CL was not associated with $\mathrm{TPCB}$ concentrations in loggerhead or olive ridley turtles (data not shown).
Homologue Composition

The PCB profiles of all three species showed somewhat similar patterns. All three were dominated by higher chlorinated homologues. Hexachlorinated biphenyls were the predominant homologues, accounting for $36-74 \%$ of the tPCB concentration (Fig. 2). Pentachlorinated biphenyls also contributed considerably to tPCBs, accounting for an additional 12-44\%. Di-, tri-, tetra-, and octachlorinated biphenyls also contributed to tPCBs in all three species, but to a lesser degree.

\section{Dioxinlike PCBs and TEQs}

Coplanar or dioxinlike PCB congeners $(77,81,105,114$, $118,123,126,156,157,167,169$, and 189) accounted for $18-46 \%$ of the tPCB concentrations in each sample (Table 2). With the exception of one loggerhead and one olive ridley turtle in which none were detected, non-orthoPCBs contributed more than $70 \%$ of the total TEQ. Mean total TEQs (tTEQs) were 42.8, 22.2, and $10.4 \mathrm{pg} / \mathrm{g}$ in loggerhead, green, and olive ridley turtles, respectively. However, no significant differences were found in the tPCB concentrations among species $(p=0.326)$. In the loggerhead turtles, a positive trend was found between CL and tTEQ concentration (data not shown; $r^{2}=0.90$,

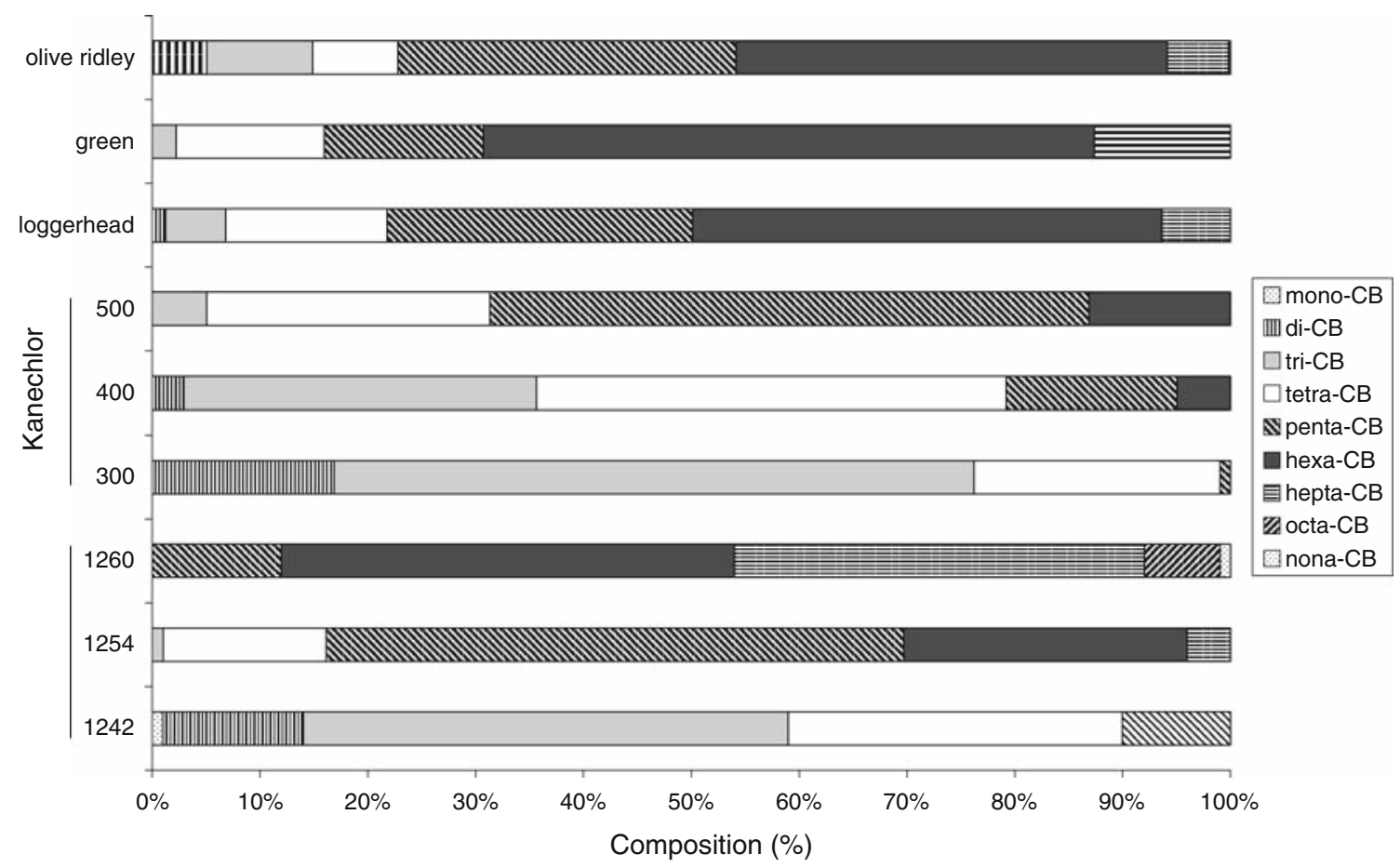

Fig. 2 Percent composition of PCB congeners in loggerhead, green, and olive ridley turtles. Also presented are the compositions of two commercial PCB mixtures 
$p=0.06$ ). However, no relationship was observed in green or olive ridley turtles (data not shown).

\section{Metabolic Group Profiles}

Polychlorinated biphenyl load normalized to congener 153 (sum molar $X / 153$ ratios) and sorted by the various metabolic groups based on vicinal proton availability are shown in Fig. 3. For each species, group 2 and group 4 were significantly lower than both group 1 and group 3 $(p<0.05)$. No significant differences were found among species.

\section{CYP Western Blotting}

Hepatic microsomal protein showed no cross-reactivity with the anti-fish CYP1A antibody, yet it did cross-react with the anti-trout CYP2K1 and anti-trout CYP3A27 antibodies (Fig. 4). There was a high degree of variability in the patterns of bands among individuals; some turtles exhibited a singlet band, whereas others displayed doublets. No correlations were observed when comparing CYP expression with $\mathrm{TPCB}$ or PCB metabolic groups.

\section{GST Activities Toward Reference Substrates}

No significant differences in cytosolic GST activity were observed among species. CDNB activities $( \pm$ SD) in olive ridley were $877 \pm 300 \mathrm{nmol} / \mathrm{min} / \mathrm{mg}$, and they were $1103 \pm 267 \mathrm{nmol} / \mathrm{min} / \mathrm{mg}$ in green sea turtles. In loggerhead turtles, the CDNB was $1047 \pm 436 \mathrm{nmol} / \mathrm{min} / \mathrm{mg}$.

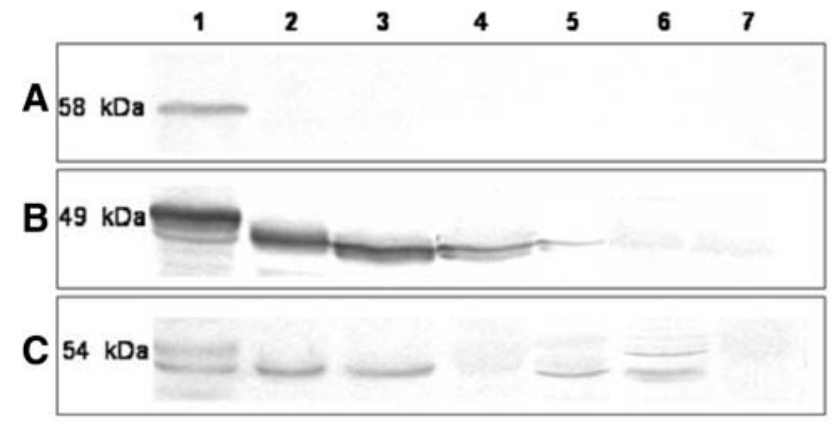

Fig. 4 Representative Western blots of microsomal a CYP1A, b CYP2K1, and c CYP3A27 proteins for rainbow trout positive control (lane 1), green (lanes 2, 3), loggerhead (lanes 4, 5), and olive ridley turtles (lanes 6, 7)

GST activities showed no significant correlation with tPCB or metabolic groups of PCBs.

\section{Discussion}

Few studies have investigated the levels of PCB contamination in sea turtles worldwide, and data for sea turtles from the Eastern Pacific are particularly sparse. The total PCB concentration of the sea turtle livers analyzed in the current study fall within the range of reported concentrations $(<3.0$ $58.1 \mathrm{ng} / \mathrm{g}$ ) from the one study on sea turtles from the BC region of Mexico (Gardner et al. 2003). Yet, when compared to reported PCB levels in the livers of sea turtles worldwide $(<1.0-1950 \mathrm{ng} / \mathrm{g}), \mathrm{BC}$ turtles contain relatively low levels (Corsolini et al. 2000; Lake et al. 1994; McKenzie et al.
Fig. 3 Sum contribution of PCBs (molar X/PCB 153) metabolic groups for loggerhead (white bars), green (gray bars), and olive ridley (black bars) turtles. Error bar indicates standard deviation. Different letters indicate significant difference within species $(p<0.05)$

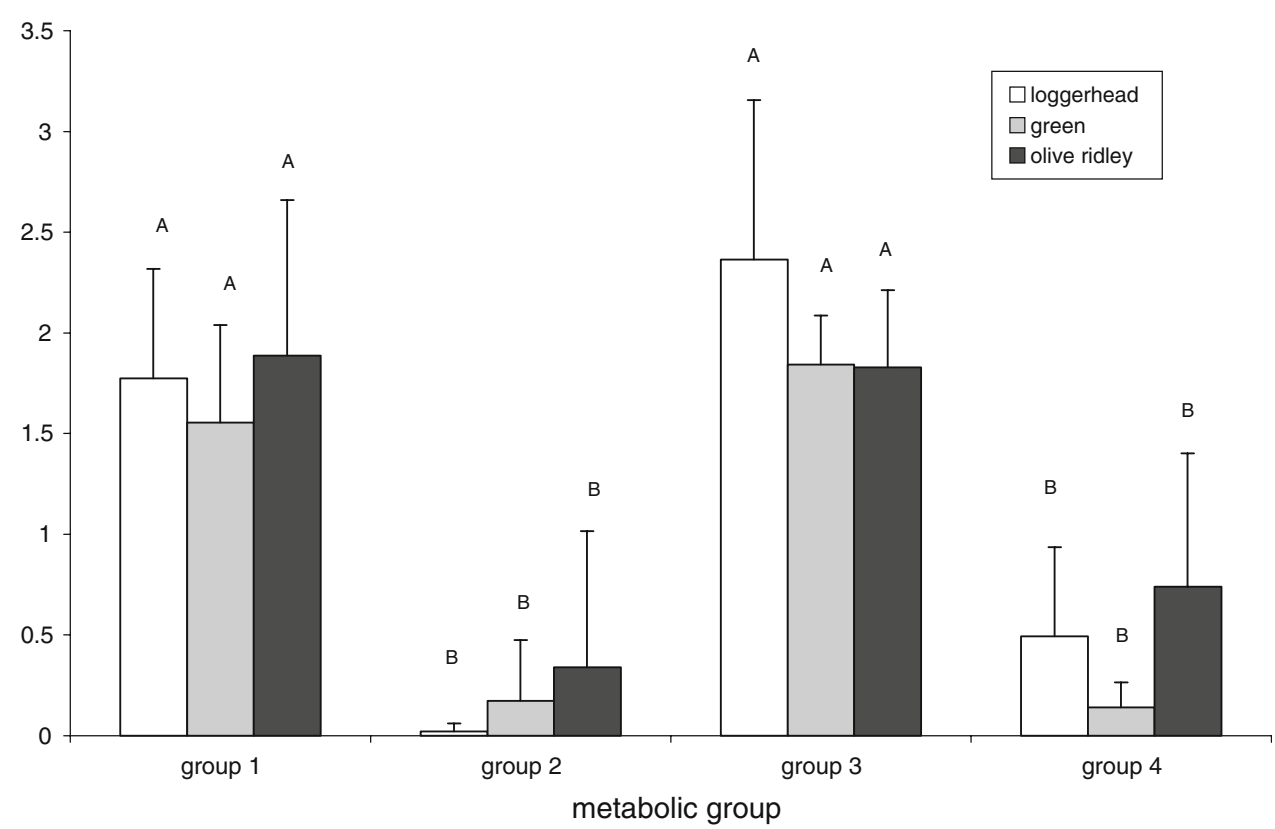


1999; Miao et al. 2001; Rybitski et al. 1995; Storelli et al. 2007; Storelli and Marcotrigiano 2000). The locality of sample collection might explain these differences, as BC is a relatively unindustrialized region of the world and would therefore be expected to have lower pollution levels than more industrialized regions. This is supported by studies of other marine inhabitants; for example, tPCB levels in California sea lions (Zalophus californianus californianus) from $\mathrm{BC}$ were found to be more than one order of magnitude less than $\mathrm{APCB}$ in sea lions from various locations throughout California (Toro et al. 2006).

The contributions of individual PCB congeners to tPCBs in loggerhead, green, and olive ridley turtles presented a similar overall pattern. The two predominant congeners, 153 and 138, showed similar relative contributions in all three species.

Congener 153 is typically the most prevalent congener reported in terrestrial and marine organisms due to the lack of vicinal protons necessary for biotransformation (Safe 1984). Furthermore, the predominance of 153 and 138 and hexachlorinated congeners is consistent with patterns reported for sea turtles worldwide, including loggerhead turtles in the Mediterranean area (Corsolini et al. 2000; Storelli et al. 2007; Storelli and Marcotrigiano 2000), green turtles in the Pacific (Miao et al. 2001), loggerhead and Kemp's ridley (Lepidochelys kempii) turtles in the Atlantic (Keller et al. 2004a; Rybitski et al. 1995).

On the basis of trophic level, species differences in PCB accumulation were previously predicted in a qualitative examination of one carnivorous olive ridley and one carnivorous loggerhead compared to seven herbivorous green turtles (Gardner et al. 2003). In contrast, the current dataset, consisting of four loggerhead, three green, and four olive ridley turtles failed to show significant differences in mean tPCB levels. However, species differences were observed for liver concentrations of non-ortho congeners.

Four non-ortho PCBs (77, 81, 126, and 169) and eight mono-ortho PCBs $(105,114,118,123,156,167,189)$ are stereoisomers of the highly toxic TCDD and have been shown to act through the same mechanism of action: binding to the AhR. The relative potency of dioxinlike PCBs can thus be calculated as TCDD TEQs using the congener concentrations and TEFs, which are based on taxa-specific relative potency at the AhR relative to TCDD (Safe 1992, 2001). Because reptile TEFs have not been determined, TEFs for birds, which range from 0.00001 to 0.1 , were used in the present study (Van den Berg et al. 1998). For all three species, non-ortho congeners accounted for more than $70 \%$ of the TEQ, similar to TEQs calculated previously for Mediterranean loggerhead turtles (Storelli et al. 2007). Congener 126 was observed in livers from one carnivorous loggerhead and one carnivorous olive ridley species but was not observed in any herbivorous green sea turtle. Congener 126 represents less than $0.01 \%$ of commonly used Aroclors (Frame 2001); thus, detection in these turtles might indicate bioaccumulation. The more abundant congener 77 was observed in two green and one loggerhead but not any olive ridley turtle. The occurrence of both congeners in loggerheads suggests that carnivorous species might be more prone to accumulation of non-ortho PCBs. The variability among turtles might result from a number of life-history factors. As oviparous organisms, sea turtle exposure to lipophilic contaminants starts in the egg and the turtles in this study might have emerged from the shell with differing levels of various PCBs depending on maternal transfer. Maternal transfer of PCBs, polyhalogenated aromatic hydrocarbons (PHAHs), and pesticides has been observed in snapping turtles (Chelydra serpentina) (Bishop et al. 1994; Kelly et al. 2008) and alligators (Alligator mississippiensis) (Rauschenberger et al. 2004). Additionally, whereas the diet of adult turtles (see Table 1) has been extensively studied through stomach content analysis, juveniles tend to show opportunistic feeding strategies (Bjorndal 1997), which could influence the PCB profiles of individual turtles; for example, a juvenile green turtle might prey upon organisms of a higher trophic level (and therefore higher predicted accumulated PCBs) than it would as an adult and therefore could exhibit growth-dilution of accumulated congeners. Additionally, it is important to note the incidental ingestion of marine debris, particularly plastics, that has been found in many sea turtles, both juveniles and adult (Bjorndal 1997). Adsorption of PCBs to the surface of hydrophobic plastics results in accumulation of PCBs at levels up to $10^{6}$ higher than surrounding seawater (Mato et al. 2001); thus, ingestion of debris might add variability to the concentrations of PCBs in the sea turtles.

The TEQs reported in the present study are higher than those reported for livers of loggerhead turtles in the Mediterranean Sea (Corsolini et al. 2000; Storelli et al. 2007) but lower than those reported in the eggs of snapping turtles from the Great Lakes (Dabrowska et al. 2006) and lower than the proposed TEQ LOEL (210 pg/g) for bald eagle chicks (Elliott et al. 1996). The discrepancy between TEQs for sea turtles might be based on the greater number of congeners detected in BC sea turtles. In loggerhead sea turtles, dioxinlike congeners and TEQs correlated with increased heterophil-lymphocyte ratios (Keller et al. 2004c), a general indicator for disease in sea turtles (Aguirre et al. 1995; Cray et al. 2001; Work et al. 2001), suggesting the possibility of dioxinlike-PCB-induced immune modulation. In the Canadian snapping turtle (Chelydra serpentina) populations, TEQs were found to be only weakly correlated with abnormal egg and hatchling development (Bishop et al. 1991, 1998), suggesting that the toxicological significance of dioxinlike compounds in reptiles is not fully understood. 
Biotransformation plays a critical role in the accumulation of xenobiotics. CYP can catalyze the direct insertion of a hydroxyl group on a precursor PCB congener or arene oxide formation (Brouwer et al. 1986; Letcher et al. 2000). Arene oxide intermediates can be conjugated with GSH catalyzed by GST, and the conjugate can then follow the mercapturic acid pathway to eventually produce methylsulfone PCB metabolites (Bakke 1989; Letcher et al. 2000; Vermeulen 1996). GST (CDNB) activity in loggerhead, green, and olive ridley sea turtles in the present study were within the range reported for green turtles collected in BC (Valdivia et al. 2007), similar to those reported for redeared slider turtles (Trachemys scripta elegans) (Willmore and Storey 1997a, b), but much higher than those reported for painted turtles (C. picta) (Rie et al. 2000). As CDNB is a generic substrate for GST, class-specific reactions known to conjugate arene oxides (i.e., GSTP) might indicate more specific interactions.

Sea turtle microsomal proteins cross-reacted with antiCYP2K1 and anti-CYP3A27 antibodies but not with antiCYP1A antibody. In alligators (A. mississippiensis), immunoblotting with anti-CYP2K also revealed proteins, which showed induction with phenobarbital and 3-methylcholanthrene and slight induction when treated with Aroclor 1254 or the nonplanar PCB 47 (Ertl et al. 1999). When stained with anti-CYP3A27 antibody, the alligator hepatic microsomes showed very low constitutive expression. However, expression was induced by phenobarbital and 3-methylcholanthrene but not by Aroclor 1254 or PCB 47 (Ertl et al. 1999). The lack of correlation of sea turtle PCBs to CYP2K1 and CYP3A27 bands and the induction patterns seen in alligators suggests that differences exist in CYP isofrom expression compared to mammals.

The CYP1 enzymes are induced in vertebrates by planar aromatic hydrocarbons via the AhR (Safe 2001). Despite the presence of planar PCBs, immunoblotting with an antibody, which recognizes a conserved peptide sequence of vertebrate CYP1A, failed to indicate the presence of CYP1A in sea turtles. This antibody was developed to recognize amino acids 277-294, which is a conserved region in all vertebrates (Rice et al. 1998). Studies in our lab with human and rat liver microsomes have shown that the antibody recognized CYP1A (data not shown). Thus, it is unlikely the antibody failed to recognize the homologous turtle protein. Unfortunately, due to biomass limitations, CYP1A catalytic activities were not performed. These results support a growing body of evidence for unique regulation and species variability of CYP1A in reptiles. In Kemp's ridley sea turtles, low P450 1A activity was observed in four partially purified P450 enzymes from the liver of wild Kemp's ridley turtles (Goldman and McClellan-Green 2001). Treatment with $400 \mathrm{mg} / \mathrm{kg}$ of Aroclor 1254 caused a fourfold to fivefold induction of CYP1A in the freshwater turtles Chrysemys picta picta and C. picta elegans but a much lower induction in another species of freshwater turtle, Mauremys caspica rivulata (Yawetz et al. 1997). Furthermore, tissues of M. caspica rivulata from sewage oxidation ponds showed no CYP1A induction, although induction was observed in other species, suggesting variability in responsiveness to CYP1A inducers (Yawetz et al. 1997). Reduced responsiveness to mammalian CYP1A inducers was demonstrated in African brown house snake (Lamprophis fuliginosus) primary hepatocytes, in which only treatment with two potent CYP1A inducers, TCDD and PCB 126, resulted in dosedependent increased CYP1A activity, whereas other CYP1A inducers, PCB 77, PCB 81, and PCB 169, caused no induction (Hecker et al. 2006). The mean $\mathrm{EC}_{50}$ values calculated for in vitro induction of CYP1A activity in these snakes were $51.52 \mathrm{ng} / \mathrm{L}(0.16 \mathrm{nM})$ and $2.67 \mu \mathrm{g} / \mathrm{L}(8.3 \mathrm{nM})$ for TCDD and PCB 126, respectively (Hecker et al. 2006). Although mean concentrations of PCB 126 in BC sea turtles (Below detection limit (BDL)-0.338 ng/g) were well below the PCB126 values, the mean calculated TEQs in $\mathrm{BC}$ sea turtles are just slightly lower than the TCDD $\mathrm{EC}_{50}$, suggesting that levels of dioxinlike PCB congeners in $\mathrm{BC}$ sea turtles might have been adequate to elicit a response in other reptiles. However, concentration response studies would be necessary to confirm this.

Structure-activity relationships suggest that PCBs can be grouped on the basis of vicinal proton position (Boon et al. 1989; McFarland and Clarke 1989; Parke 1985). In all three species of sea turtles examined in the current study, molar ratios of group 3 congeners, which possess only $o-m$ vicinal protons and are substrates for CYP1A in mammals, were significantly higher than that of group 2 and 4 congeners, which contain $m-p$ vicinal protons and are CYP2B substrates. In fact, group 3 congeners showed no difference from the poorly metabolized group 1 congeners, which lack vicinal protons. The same pattern (higher relative levels of CYP1A substrates/congeners and low levels of CYP2B substrates/congeners) was observed in loggerhead and Kemp's ridley turtles in the Atlantic (Keller et al. 2004a). Thus, the specific accumulation of CYP1A substrates in sea turtles might indicate poor biotransformation, which is consistent with limited CYP1A expression in these species.

In conclusion, PCB levels in loggerhead, green, and olive ridley turtles from the $\mathrm{BC}$ region of Mexico are generally lower than those reported for turtles from more polluted regions of the globe. The presence of dioxinlike congeners and relatively high TEQs along with a lack of CYP1A expression suggest a potential mechanism of accumulation of group 1 congeners. Future studies might clarify the contributions of CYP and GST isoforms toward the biotransformation and accumulation of PCBs in sea turtles. 
Acknowledgments The authors express their appreciation to the members of Grupo Tortuguero for their support in sea turtle specimen collection. Dr. Janet Arey of UCR provided invaluable comments on PCB data. Dr. Donald Buhler of Oregon State University generously provided CYP2K1 and CYP3A27 antibodies. Convention on International Trade in Endangered Species (CITES) permits were obtained for international export (MX 30379) and import (US 06US115655/9) of sea turtle tissues.

Open Access This article is distributed under the terms of the Creative Commons Attribution Noncommercial License which permits any noncommercial use, distribution, and reproduction in any medium, provided the original author(s) and source are credited.

\section{References}

Aguirre AA, Balazs GH, Spraker TR, Gross TS (1995) Adrenal and hematological responses to stress in juvenile green turtles (Chelonia mydas) with and without fibropapillomas. Physiol Zool 68:831-854

Bakke JE (1989) Metabolites derived from glutathione conjugation. In: Hutson DH, Caldwell J, Paulson GD (eds) Intermediary xenobiotic metabolism in animals. Taylor \& Francis, London, pp 205-224

Bishop CA, Brooks RJ, Carey JH, Ng P, Norstrom RJ, Lean DRS (1991) The case for a cause-effect linkage between environmental contamination and development in eggs of the common snapping turtle (Chelydra serpentina) from Ontario, Canada. J Toxicol Environ Health 33:521-547

Bishop CA, Brown GP, Brooks RJ, Lean DRS, Carey JH (1994) Organochlorine contaminant concentrations in eggs and their relationship to body-size, and clutch characteristics of the female common snapping turtle (Chelydra-serpentina serpentina) in Lake Ontario, Canada. Arch Environ Contam Toxicol 27:82-87

Bishop CA, Ng P, Pettit KE, Kennedy SW, Stegeman JJ, Norstrom RJ, Brooks RJ (1998) Environmental contamination and developmental abnormalities in eggs and hatchlings of the common snapping turtle (Chelydra serpentina serpentina) from the Great Lakes St Lawrence River basin (1989-91). Environ Pollut 101:143-156

Bjorndal KA (1997) Foraging ecology and nutrition of sea turtles. In: Lutz PL, Musick JA (eds) The biology of sea turtles. CRC Press, Boca Raton, FL, pp 199-232

Boon JP, Eijgenraam F, Everaarts JM, Duinker JC (1989) A structure activity relationship (SAR) approach towards metabolism of $\mathrm{PCBs}$ in marine animals from different trophic levels. Marine Environ Res 27:159-176

Brogdon WG, Dickinson CM (1983) A micro-assay system for measuring esterase-activity and protein-concentration in small samples and in high-pressure liquid-chromatography eluate fractions. Anal Biochem 131:499-503

Brouwer A, van den Berg KJ, Blaner WS, Goodman DS (1986) Transthyretin (prealbumin) binding of PCBs, a model for the mechanism of interference with vitamin A and thyroid hormone metabolism. Chemosphere 15:1699-1706

Clifton K, Cornejo DO, Felger R (1982) Sea turtles of the Pacific coast of Mexico. In: Bjorndal KA (ed) Biology and conservation of sea turtles. Smithsonian Institute Press, Washington, pp 199-209

Corsolini S, Aurigi S, Focardi S (2000) Presence of polychlorobiphenyls (PCBs) and coplanar congeners in the tissues of the Mediterranean loggerhead turtle Caretta caretta. Marine Pollut Bull 40:952-960
Cray C, Varella R, Bossart GD, Lutz P (2001) Altered in vitro immune responses in green turtles (Chelonia mydas) with fibropapillomatosis. J Zool Wildl Med 32:436-440

Dabrowska H, Fisher SW, Estenik J, Kidekhel R, Stromberg P (2006) Polychlorinated biphenyl concentrations, congener profiles, and ratios in the fat tissue, eggs, and plasma of snapping turtles (Chelydra serpentina) from the Ohio Basin of Lake Erie, USA. Arch Environ Contam Toxicol 51:270-286

Elliott JE, Norstrom RJ, Lorenzen A, Hart LE, Philibert H, Kennedy SW, Stegeman JJ, Bellward GD, Cheng KM (1996) Biological effects of polychlorinated dibenzo-p-dioxins, dibenzofurans, and biphenyls in bald eagle (Haliaeetus leucocephalus) chicks. Environ Toxicol Chem 15:782-793

Ertl RP, Bandiera SM, Buhler DR, Stegeman JJ, Winston GW (1999) Immunochemical analysis of liver microsomal cytochromes P450 of the American alligator, Alligator mississippiensis. Toxicol Appl Pharmacol 157:157-165

Frame G (2001) Congener-specific PCB analysis. In: Cazes J (ed) Encyclopedia of chromatography. CRC Press, Boca Raton, FL, pp 192-195

Gardner SC, Pier MD, Wesselman R, Juarez JA (2003) Organochlorine contaminants in sea turtles from the Eastern Pacific. Marine Pollut Bull 46:1082-1089

Goldman R, McClellan-Green PD (2001) Isolation and characterization of P450 enzymes from Kemp's ridley (Lepidochelys kempii) liver. In: SETAC 22nd annual meeting, 11-15 November, Baltimore, MD (Abtract \#328)

Habig WH, Jakoby WB (1981) Assays for differentiation of glutathione $S$-transferases. Methods Enzymol 77:398-405

Hecker M, Murphy MB, Giesy JP, Hopkins WA (2006) Induction of cytochrome P4501A in African brown house snake (Lamprophis fuliginosus) primary hepatocytes. Environ Toxicol Chem 25: 496-502

IUCN (2008) 2008 IUCN red list of threatened species. International Union for Conservation of Nature and Natural Resources. www.redlist.org. Accessed 24 December 2008

James MO (2001) Polychlorinated biphenyls: metabolism and metabolites. In: Roberston LW, Hansen LG (eds) PCBs: recent advances in environmental toxicology and health effects. The University of Kentucky Press, Lexington, pp 35-46

Kannan N, Reusch TBH, Schulzbull DE, Petrick G, Duinker JC (1995) Chlorobiphenyls: model compounds for metabolism in food-chain organisms and their potential use as ecotoxicological stress indicators by application of the metabolic slope concept. Environ Sci Technol 29:1851-1859

Keller JM, Kucklick JR, Harms CA, McClellan-Green PD (2004a) Organochlorine contaminants in sea turtles: correlations between whole blood and fat. Environ Toxicol Chem 23:726-738

Keller JM, Kucklick JR, McClellan-Green PD (2004b) Organochlorine contaminants in loggerhead sea turtle blood: extraction techniques and distribution among plasma and red blood cells. Arch Environ Contam Toxicol 46:254-264

Keller JM, Kucklick JR, Stamper MA, Harms CA, McClellan-Green PD (2004c) Associations between organochlorine contaminant concentrations and clinical health parameters in loggerhead sea turtles from North Carolina, USA. Environ Health Perspect 112:1074-1079

Kelly SM, Eisenreich KM, Baker JE, Rowe CL (2008) Accumulation and maternal transfer of polychlorinated biphenyls in snapping turtles of the upper Hudson River, New York, USA. Environ Toxicol Chem 27:2565-2574

Lake JL, Haebler R, McKinney R, Lake CA, Sadove SS (1994) PCBs and other chlorinated organic contaminants in tissues of juvenile Kemp's ridley turtles (Lepidochelys kempi). Marine Environ Res $38: 313-327$ 
Letcher RJ, Klasson-Wehler E, Bergman A (2000) Methyl sulfone and hydroxylated metabolites of polychlorinated biphenyls. In: Paasivirta J (ed) New types of persistent halogenated compounds. Springer-Verlag, Berlin, pp 317-357

Mast RB, Hutchinson BJ, Howtage E NJP (2005) IUCN/SSC marine turtle specialist group hosts the second burning issues assessment workshop. Marine Turtle Newslett 110:13-15

Mato Y, Isobe T, Takada H, Kanehiro H, Ohtake C, Kaminuma T (2001) Plastic resin pellets as a transport medium for toxic chemicals in the marine environment. Environ Sci Technol 35:318-324

McFarland VA, Clarke JU (1989) Environmental occurrence, abundance, and potential toxicity of polychlorinated biphenyl congeners: considerations for a congener-specific analysis. Environ Health Perspect 81:225-239

McKenzie C, Godley BJ, Furness RW, Wells DE (1999) Concentrations and patterns of organochlorine contaminants in marine turtles from Mediterranean and Atlantic waters. Marine Environ Res 47:117-135

Miao XS, Balazs GH, Murakawa SKK, Li QX (2001) Congenerspecific profile and toxicity assessment of PCBs in green turtles (Chelonia mydas) from the Hawaiian Islands. Sci Total Environ 281:247-253

Mullin MD, Pochini CM, McCrindle S, Romkes M, Safe SH, Safe LM (1984) High-resolution PCB analysis: synthesis and chromatographic properties of all 209 PCB congeners. Environ Sci Technol 18:468-476

Parke DV (1985) The role of cytochrome P-450 in the metabolism of pollutants. Marine Environ Res 17:97-100

Rauschenberger RH, Sepulveda MS, Wiebe JJ, Szabo NJ, Gross TS (2004) Predicting maternal body burdens of organochlorine pesticides from eggs and evidence of maternal transfer in Alligator mississippiensis. Environ Toxicol Chem 23:2906-2915

Rice CD, Schlenk D, Ainsworth J, Goksoyr A (1998) Cross-reactivity of monoclonal antibodies against peptide 277-294 of rainbow trout CYP1A1 with hepatic CYP1A among fish. Mar Environ Res 46:87-91.

Richardson KL, Gold-Bouchot G, Schlenk D (2009) The characterization of cytosolic glutathione transferase from four species of sea turtles: loggerhead (Caretta caretta), green (Chelonia mydas), olive ridley (Lepidochelys olivacea), and hawksbill (Eretmochelys imbricata). Comp Biochem Physiol, Part C 150:279-284

Rie MT, Lendas KA, Woodin BR, Stegeman JJ, Callard IP (2000) Hepatic biotransformation enzymes in a sentinel species, the painted turtle (Chrysemys picta), from Cape Cod, Massachusetts: seasonal-, sex- and location-related differences. Biomarkers 5:382-394

Rowe CL (2008) "The calamity of so long life": life histories, contaminants, and potential emerging threats to long-lived vertebrates. Bioscience 58:623-631

Rybitski M, Hale R, Musick J (1995) Distribution of organochlorine pollutants in Atlantic sea turtles. Copeia 2:379-390
Safe S (1984) Polychlorinated biphenyls (PCBs) and polybrominated biphenyls (PBBs): biochemistry, toxicology, and mechanism of action. CRC Crit Rev Biochem 13:319-395

Safe S (1992) Development, validation and limitations of toxic equivalency factors. Chemosphere 25:61-64

Safe SH (1994) Polychlorinated biphenyls (PCBs): environmental impact, biochemical and toxic responses, and implications for risk assessment. Crit Rev Toxicol 24:87-149

Safe S (2001) PCBs as aryl hydrocarbon receptor agonists: implications for risk assessment. In: Roberston LW, Hansen LG (eds) Recent advances in environmental toxicology and health effects. University of Kentucky Press, Lexington, pp 171-177

Sapozhnikova Y, Bawardi O, Schlenk D (2004) Pesticides and PCBs in sediments and fish from the Salton Sea, California, USA. Chemosphere 55:797-809

Storelli MM, Marcotrigiano GO (2000) Chlorobiphenyls, HCB, and organochlorine pesticides in some tissues of Caretta caretta (Linnaeus) specimens beached along the Adriatic Sea, Italy. Bull Environ Contam Toxicol 64:481-488

Storelli MM, Barone G, Marcotrigiano GO (2007) Polychlorinated biphenyls and other chlorinated organic contaminants in the tissues of Mediterranean loggerhead turtle Caretta caretta. Sci Total Environ 373:456-463

Toro Ld, Heckel G, Camacho-Ibar VF, Schramm Y (2006) California sea lions (Zalophus californianus californianus) have lower chlorinated hydrocarbon contents in northern Baja California, Mexico, than in California, USA. Environ Pollut 142:83-92

Valdivia PA, Zenteno-Savin T, Gardner SC, Aguirre AA (2007) Basic oxidative stress metabolites in eastern Pacific green turtles (Chelonia mydas agassizii). Comp Biochem Physiol C 146:111117

Van den Berg M, Birnbaum L, Bosveld ATC, Brunstrom B, Cook P, Feeley M, Giesy JP, Hanberg A, Hasegawa R, Kennedy SW, Kubiak T, Larsen JC, van Leeuwen FXR, Liem AKD, Nolt C, Peterson RE, Poellinger L, Safe S, Schrenk D, Tillitt D, Tysklind M, Younes M, Waern F, Zacharewski T (1998) Toxic equivalency factors (TEFs) for PCBs, PCDDs, PCDFs for humans and wildlife. Environ Health Perspect 106:775-792

Vermeulen NPE (1996) Role of metabolism in chemical toxicity. In: Ioannides C (ed) Cytochromes P450: metabolic and toxicological aspects. CRC Press, Boca Raton, FL, pp 29-54

Willmore WG, Storey KB (1997a) Antioxidant systems and anoxia tolerance in a freshwater turtle Trachemys scripta elegans. Mol Cell Biochem 170:177-185

Willmore WG, Storey KB (1997b) Glutathione systems and anoxia tolerance in turtles. Am J Physiol Regul Integr Comp Physiol 42:R219-R225

Work TM, Rameyer RA, Balazs GH, Cray C, Chang SP (2001) Immune status of free-ranging green turtles with fibropapillomatosis from Hawaii. J Wildl Dis 37:574-581

Yawetz A, Benedek-Segal M, Woodin B (1997) Cytochrome P4501A immunoassay in freshwater turtles and exposure to PCBs and environmental pollutants. Environ Toxicol Chem 16:1802-1806 